\title{
Critical Dialogue on Creating Public Value: The Comparisons of Confucian Value, Socialist Core Value, Universal Value and Public Value
}

\author{
SONG Jinzhou \\ East China Normal University, Shanghai, China
}

\begin{abstract}
The Creating Public Value Theory by Mark Moore is more and more accepted all over the world. China has been a value-oriented society for all her history. However, China has been dominated by the Confucian ethics and modern political elite values, especially traditional instilled civil servants values and modern socialist core value. The public value of China has been highly cultured and localized. This paper tries to review briefly and make the critical comments on the following issues: (1) Confucian value; (2) the socialist core value; (3) the universal value; (4) the human common value; and (5) the public value. The paper highlights what differences of conceptualizing public value between China and the Western countries.
\end{abstract}

Keywords: Creating Public Value Theory, Confucian ethics, Socialist core value, universal value, public value

Each culture has its own unique set of systems. Values are the rules of people's behavior, the way of thinking, the criterion of cognition, the philosophy of life, the model of deductive reasoning, the norms of evaluating things, and the standards of morality. Generally, the traditional Chinese culture value is composed of Confucianism, Buddhism, and Taoism, and Confucianism is the dominant ethic value. The family structure based on patriarchal blood was also the basic structure of feudal kingdoms since the Western Zhou Dynasty (1046-771 BC). A whole set of courtesies in feudal society were all based on family structure/pattern in ancient China.

\section{Confucian Values}

\section{Traditional Core Values: "Three Cardinal Guides" and "Five Virtues"}

The Confucian value became a dominant national value since the Eastern Han Dynasty. China's feudal orthodox ethics is entering the feudal society after Qin Dynasty, and the early Western Han Dynasty for 80 years of emperor period (141-87 BC) gradually formed. It is the important tool of political domination and culture. Basically, it is to meet the need of maintenance and strengthening feudal unification.

Three Cardinal Guides. It means rulers and stakeholders should be loyal to each other. Parents and children should love each other, and husbands and wives should live in harmony. This is the traditional Chinese core ethics for the whole Chinese society.

Five Virtues. Benevolence (ren) and righteousness (yi) are the core values in Pre-Qin Dynasty (before

SONG Jinzhou, Ph.D., Associate Professor, Department of Public Administration, East China Normal University, Shanghai, China. 
$221 \mathrm{BC}$ ). Confucian ritual ethics is composed of benevolence (ren), righteousness (yi), and propriety (li). Mencius ritual ethics includes benevolence (ren), righteousness (yi), propriety (li), and wisdom (zhi). Dong Zhongshu in the Eastern Han Dynasty extends the basic values to benevolence (ren), righteousness (yi), propriety $(l i)$, wisdom $(z h i)$, and trustworthiness (xin), which is called "Five Virtues" and they should be strictly adhere to and should not be violated in the society.

Benevolence (ren). It embodied in politics is to emphasize on "virtues", which is the basic spirit of the universal love. Confucius in the introduction of politeness changed the traditional "rule by propriety" as "virtue", he did not deny "rule by propriety". His "virtue" is the inheritance and transformation of "rule by propriety". The essence of love for both the kernel and basic content, and this kind of love is "work", by the family love and expanding into the benevolence.

Righteousness (yi). It refers to "appropriate", namely the behavior is suitable for "propriety" at the beginning. Confucius takes "righteousness" as people's thought and behavior of moral principles. "Righteousness" has a "gentleman's righteousness", and the "ego small righteousness", such as a small party group. For the masses and for the society, it is "the big righteousness".

Propriety (li). It is Confucius and Confucian politics and ethics. In the long history of development, "propriety" as China's feudal society's ethics and living standards, it has played an important role in the cultivation of mental quality. In the late feudal society, it is more and more limit people's thoughts, behaviors, social progress, and development.

Wisdom (zhi). Confucius's basic category is epistemology and ethics. To know and understand the insight, knowledge, intelligence, etc., Connotation mainly relates to know the nature, source, know contents, and know the effects. According to Confucius, knowledge is a moral category, and is a person's behavior.

Trustworthiness (xin). It refers to treat people doing thing honestly without deceiving, keep his words. Confucius "trustworthiness" as the important of "benevolence", is essential character of the gentleman, in speech and behavior to achieve the true, and can win the trust of others.

Four Books. These are China's Confucian classic ethics books, which were adopted in ancient civil servants examinations (607-1905). "Four Books" refer to Analects of Confucius, Mencius, University, and Doctrine of the Middle Path by Zhu Xi in the Southern Song Dynasty.

Five Classics. Poetry, History, Rites, Change (Zhouyi), and Spring and Autumn Annals.

Four Dimensions. Propriety (li), righteousness (yi), incorrupt (lian), and shame (chi).

Eight Virtues. Loyalty (zhong), filial piety (xiao), benevolence (ren), care (ai), faith (xin), righteousness (yi), harmony (he), and peace (ping). They are the life value orientation of self-cultivation, family, governance and the world, which is also the cognitive value orientation of respect for the elder.

\section{Comments}

"Three Cardinal Guides" take "to worship parents in the family" and "to worship the Kingdom" as the core ethics/principles. The requirement is to establish and follow the rank the noble and the bitch, the relatives and others, the respected and the humble, the supervisor and subordinates, and the elder and the younger very strictly. The litigation should know the social hierarchy. The poor people in front of the law should maintain the imperial power inviolable first. The second is to maintain the privileges of other "honor person" and the family within the scope of the inequality relationship, and to maintain the privilege of parents. These reflect the feudal orthodox ethics about the maintenance of all feudal privileges and principles. 
The ethics moralized, first taught. In view of the Han Dynasty and Qin Dynasty were "full penalty" in punishment relationship with particular emphasis on, and the leading role of stress after ethics first. Put the moral education in the major position and continue to the end of feudal society.

Confucius, the founder of the Confucian ethics thoughts, is based on the family as the standard, by ethics as the center, based on the level of social system. "Rule by propriety" and "virtue", that is, the "rule of man". Confucian rule is: The Saint making decision, the routine behaviors ethically regulated, and following the model of king. Confucianism emphasizes the Confucian on the propriety and law, in the relation between ethics and law emphasizing on virtues, in the relationship between human and law emphasizing on "rule of man". Since the Han Dynasty "ousted hundreds of thoughts", Confucianism became the dominant ethics, which has been lasting in China for more than 2,000 years. The feudal ethics is essentially the Confucian ethics, it still have a profound impact on current China's political, economic, social, cultural, education, behavior, legality, etc.

Follow the classic ethics and its meaning, and punishment judged from doctrine of the Confucian classics. The establishment of the code of Tang Dynasty was reasonable by ritual and moral doctrine of the Confucian classics, and then implemented by law. Song Dynasty, Yuan Dynasty, Ming Dynasty, and Qing Dynasty follow the code of behavior. But all the trials must emphasize and follow the classic ethics and its meaning. The punishment is judged from doctrine of the Confucian classics. The law must still be in accordance with "righteousness".

\section{Other Ethic Virtues}

Other virtues are gentle (wen), modest (liang), courteous (gong), restrained (jian), and magnanimous (rang); faithful (zhong), piety (xiao), incorrupt (lian), shame (chi), and brave (yong).

\section{Comments}

“Three Cardinal Guides" instead of "virtues" as legal standard. Dong Zhongshu emphasized the state was managed with moral code of conduct and justice.

The ideas of "self-struggle", "noble and generous mind", and "unity of the heaven and man" have embodied the national ethos of China.

Perfect personality is the goal of the society. It can work well on assuring the social order, and adjust the social relationship to govern the country by combining the rule of law and the rule of virtues.

Implication for modern society: Chinese traditional culture concerns for harmony between human beings and nature, human beings and social groups, person and person, person and self, which are the conflicts of human beings resulted in ecological, social, ethic, spiritual, and value crises. The harmonious ethics become the possible terminal value in the world.

The traditional culture for resolving the conflicts of humanity. In the modern society, mankind is faced with all kinds of conflicts: Man and nature, man and society, human and human, human and self, and different civilizations. They cause the biological, ecological, moral, social, and spiritual crisis.

Chinese traditional culture is a kind of ethical culture. The most important foundation, patriarchal clan system is based on kinship ties, which largely determines China's social and political structure, and ideology. Mencius said, the world both in the kingdom and at home. This idea highly summarizes the essence of Chinese traditional society. The homogeneous patriarchal system constructs the ethics of Chinese culture. 


\section{The Socialist Core Values}

\section{Chinese National Values}

Prosperity. To be rich and strong is the cherished wish of the Chinese nation, and the material basis for the prosperity and well-being of the nation.

Democracy. Democracy is the beautiful pursuit of human society. The democracy pursued is the people's democracy. The essence and core of the democracy is that the people are the masters of the country, and it is the political guarantee to create a happy life for the people.

Civility. Civilization is an important symbol of social progress. It is a generalization of the socialist culture oriented towards the world facing the future and the science of the nation.

Harmony. Harmony is the basic concept of Chinese traditional culture, and it embodies the situation of learning to have a good living.

\section{Chinese Social Values}

Freedom. Western value defines "freedom" as an individual right to do certain things. Traditional Chinese value defines a pair relationship instead of individual rights. Freedom refers to the free existence and development of human will, which is a beautiful wishes of human society and a social value goal pursued.

Equality. The equality of material conditions and opportunities are basic socialist values. Equality means that all citizens are equal before the law. Their value orientation is to achieve substantive equality. It requires the respect and protection of human rights, and everyone enjoys equal rights to participate in the development of equality.

Justice. Justice is social equity and social justice. It is the premise of the free and equal rights of human emancipator, and is the fundamental value of the society.

Rule of law. Rule of law is the basic way of governing; the rule of law constitutes the essential requirement of socialist democracy to maintain it through legal construction and safeguard the fundamental interests of the citizens, and is the guarantee of freedom, equality, fairness and justice system.

\section{Chinese Individual Value}

Patriotism. The patriotic is based on individual's deep feelings of their motherland dependencies, and adjusts the relationship between people and the motherland's code of conduct. It requires people promote national unity, safeguard the unity of the motherland, and conscientiously serve the motherland.

Dedication. Dedication is the value evaluation of the civil code of professional conduct, which requires the citizens to be loyal to their duties, to serve the people, to serve the society, to fully reflect the socialist goal.

Integrity. Honesty and trustworthiness is the moral tradition that has been passed down by human society for thousands of years. It is also the key of moral construction, and emphasizes that honest labor keeps its promises and treats people with sincerity.

Friendship. It emphasizes that citizens should respect, and care for each other, and be friendly each other.

\section{Comments}

The socialist core values are people-oriented, propriety-oriented, rule of law spirit, benevolence spirit, and integrity. The biggest idea is the universal value of democracy, freedom, equality, justice, listed in the socialist core values, marked the concept of China being closer to the modern society. China advocates cultivating socialist core values including freedom, democracy, human rights and other concepts in the Western countries. The socialist core value is to promote patriotism and collectivism values. 
Ethical culture and legal culture. Chinese culture is the ethical culture while Western culture is the legal culture for governing the country. Chinese culture advocates establish a good ethics to regulate the social behaviors, through education to make people have the self-discipline consciousness, overcome the personal desires, comply with social norms, and maintain a good social order.

Western culture thinks that human nature is evil and original sins from the perspective of evil. It thinks that life is guilty, and advocates establish strict laws to curb the individual desires and animal instinct. With heteronomy to make people abide by the social norms, and maintain the social order.

\section{The Universal Value}

A value is a universal value if it has the same value or worth for all people. Spheres of human value encompass morality, aesthetic preference, human traits, human endeavour, and social order. Whether the universal value exists is an unproven conjecture of moral philosophy and cultural anthropology. The claim for universal value can be understood in two different ways. First, it could be that something has a universal value when everybody finds it valuable. Second, something could have universal value when all people have reason to believe it has value. Many different things have been claimed to be of universal value, such as fertility, pleasure, and democracy.

\section{Philosophic Universal Value}

The principle areas of philosophy concerned with values are axiology and value theory, but values also play an important role in ethics, aesthetics, and political philosophy.

\section{Ethic Universal Value}

The universal value plays a different role in virtue ethics, deontological and teleological or consequentialist moral theories. Consequentialist theories are based on the idea that right actions are those that lead to a result that has universal value. Some utilitarians, such as Jeremy Bentham (1789) have argued that pleasure and pain are the only things that are of universal intrinsic value, that pleasure and pain are the only things that are valued for themselves, and other things are of value only because they produce pleasure or pain. Because utilitarian is a consequentialist, which means that utilitarian who hold pleasure and pain to be the only things of universal value then argue that actions are right when they maximize pleasure and minimize pain, when everyone is considered equally.

\section{Psychological Universal Values}

Schwartz (1994) had carried out empirical research investigating whether there are universal values, and what those values are. Schwartz defined "values" as conceptions of the desirable that influence the way people select action and evaluate events. He hypothesized that universal values would relate to three different types of human need: Biological needs, social co-ordination needs, and needs related to the welfare and survival of groups. Schwartz's (1994) 10 types of universal value are: (1) power: authority; leadership; dominance, social power, wealth; (2) achievement: success; capability; ambition; influence; intelligence; self-respect; (3) hedonism: pleasure; enjoying life; (4) stimulation: daring activities; varied life; exciting life; (5) self-direction: creativity; freedom; independence; curiosity; choosing your own goals; (6) universalism: broad mindedness; wisdom; social justice; equality; a world at peace; a world of beauty; unity with nature; protecting the environment; inner harmony; (7) benevolence: helpfulness; honesty; forgiveness; loyalty; responsibility; friendship; (8) tradition: accepting one's portion in life; humility; devoutness; respect for tradition; moderation; 
(9) conformity: self-discipline; obedience; and (10) security: cleanliness; family security; national security; stability of social order; reciprocation of favors; health; sense of belonging. Schwartz also tested the possible universal value of spirituality or the goal of finding meaning in life, but found that it does not seem to be recognized in all cultures.

Rokeach's (1973) values survey shows that: (1) The system of ultimate values used to represent the idealized end state or result of existence, including a comfortable life, an uplifting life, a sense of accomplishment, a peaceful world, a beautiful world, equality, family security, freedom, happiness, inner peace, mature love, national security, enjoyment, salvation of the soul, self-esteem, social recognition, true friendship, and wisdom. (2) The instrumental value system is the way or means of behavior used to achieve the ultimate state of idealization, including ambitious, broad-minded, talented, happy, neat, brave, helpful, honest, imaginative, independent, rational, logical, loving, obedient, educated, responsible, self-control, and kind.

\section{Universal Value Committed in China}

Hu Jintao (2003) thinks that:

Democracy is the common pursuit of all mankind, (p. 1)

Wen Jiabao (2007) thinks that:

science, democracy, rule of law, freedom, human rights, equality, love, etc. is not specific for capitalism, and this is cofounded civilized achievement throughout the whole human beings history, which is the shared values to seek for of the whole human beings. (p.1)

Wen Jiabao (2012) thinks that:

Democracy, rule of law, fairness and justice, freedom and equality are the common ideals and goals of mankind. (p. 1)

Xi Jinping (2015) thinks that:

Peace, development, fairness, justice, democracy and freedom are the common values of all mankind. (p. 1)

The universal value is beyond nationality, race, national boundaries, and beliefs, and other values with the whole of mankind. It is a minimal measure of right and wrong, good and evil, and human moral bottom line.

1. Democracy: Democracy is by all citizens, directly or through their freely elected representatives, the exercise of power and civic responsibility of the government. It is a series of principles and behaviors to protect human freedom. It is the majority rule, coupled with individual and minority rights. It respects the will of the majority, and protects the fundamental rights of individuals and minority groups.

2. Rule of law: Universally comply with the law, and obey the law and make a good law. The superiority of the rule of law: The law is the collective wisdom and prudent consideration. The law has no feelings, no groups with fairness. The law does not speak. The law is formal and clear.

3. Freedom: Freedom refers to an individual basic rights and free will. Each of us must learn to discipline ourselves and take the necessary responsibility, so as not to interfere with the free will and inherent rights of others, not from big principle of justice.

4. Fairness: It is not the absolute average of material wealth, and refers to the balanced competition opportunity and basic human rights of equality. It simply is not a privileged in the rules, and everyone is equal before the law. 
5. Human rights: First is the right to life, such as the right of the person from harm; the right of freedom from fear and hunger; the right of the treatment of disease to maintain health. Second is liberty, such as the right to freedom of speech and writing; Right to freedom of action, the migration, assembly; the right to freedom, of freedom, of thought and belief. Third is the pursuit of happiness. Because race, nationality, region, religion, politics, physical defect reason to suffer any kinds of discrimination.

6. Justice: It is truth, and it is the end result of the people's behavior and things. It must conform to the logic, and moral norms. Without fairness and justice, freedom cannot be established. Without fairness and freedom, justice is impossible. Fairness, justice, and freedom, the three interdependent elements are inseparable, which is a holistic concept.

7. Equality: Value, quality, character, ability, or condition with others are equal before the law. Especially in enjoying treatment or privileges equal with others. All lives are equal.

8. Love: It is a wide range of love for all mankind. Since the love object is the mankind, so love is to have a care each other, help each other between people. "Everyone equal" is the most basic condition. The simplest definition of love is to have a kind of enthusiast heart to others, to help all the people who need to care about.

\section{Comments}

Task-oriented and relationship orientation. Chinese people focus on the relationship orientation. To keep harmonious relationship is more important than to complete the task. Americans, by contrast, focus on the task orientation. To complete the work often is more important than the relationship. Obligations between Chinese people and relationships with others often mean mutual obligations. In contrast, Americans tend to avoid interdependent relationships that may lead to long-term obligations of the situation.

Harmony and "fact". The Chinese usually avoids the direct conflict, public criticism, and controversial issues. They want to maintain harmony in the surrounding people, leave "face" for others. On the contrary, Americans usually directly face the problems, criticize, and discuss controversial issues. He/she insists that he/she thinks it is factual opinion.

The role of laws, rules and regulations. In terms of communication, the Chinese people are usually more trusted relationships (guan xi), but not too much trusted in the written rules and procedures. Americans generally believe that the written rules apply to everyone, and can produce fair and reasonable procedures and decisions.

The different relationship between man and nature. Chinese culture focuses on people. The interpersonal relationship is the core concern of Chinese culture, based on the real life, and quite developed political ethics. While the Western culture is more focused on the nature, the relationship between human and nature is the center of the ancient Greek, which pays attention to the problems, reasoning, science and technology. Chinese philosophy is a philosophy of life, immortality as Confucianism, Taoism, Buddhism and enlightenment. Confucianism as the orthodox school, the core of it is benevolence. What is benevolence? Confucius said, love is to learn how to be a person and be interested in interpreting manner, e.g., father and son is a set of ethical relationship between people. The purpose of cultivating one's morality level is to realize his own political ambitions to run the country well.

The important features of Chinese culture are the "nature and humanity". The natural personification melts the pursuit of the human spirit in nature, human and the nature harmonious state of breathing. 
In terms of cultural and social relations, culture influences society in different cultures. Chinese culture is given priority to virtues (de). Rule of law is complementary, mainly through education to solve the relationship problems of the people. By authority and power to maintain social order, Western cultures are given priority to rule of law. Morality is complementary, advocated by establishing strict laws to handle interpersonal relationships, through the establishment of various systems and norms to maintain social order.

For culture and personal relations, culture influences individuals. The different types of cultures bring up different types of people. That is cultivating what kind of Chinese culture, such as kindness, duty, honest person, or good person as the basic purpose. Pay attention to the enlightenment and the heavy mind cultivation through the depressive personality. Pay attention to desires to regulate behavior through education, training to improve people's self-discipline consciousness. The formation of the self-discipline consciousness is "moral self-discipline" formed in the moral driven. Each person has a conscience of incorrupt and shames through enlightenment. A traditional Chinese was described as "the kind father, the filial son, and the good brother" with righteousness, wisdom, and loyalty to the traditional culture.

Emphasize on people and humanities. Chinese culture focuses on humanity, human life, ethics and character, human and human nature. All Confucian ideology is in people as a starting point, and develops well in people. The family standard of Chinese culture takes a family as unit of society. The family, the clan, and interpersonal relationship are characterized by interdependence. Families and clans link, based on blood relationship: Everyone is fixed to the relationship of various social needs, which can be satisfied in the family/clan.

The Complementarity between Chinese and Western culture. Chinese culture is a mixture of a variety of cultures, and has her own inherence. There are very few pure ethnic cultures in the world. Russell (2000) believed that Western civilization must learn something valuable from the Chinese civilization. He appreciated China's cultural implication of peace. Chinese culture advocates nature and humanity, harmony, the doctrine of middle-path-way, righteousness and propriety wisdom and filial piety.

Chinese culture belongs to ethical culture, and the Western culture belongs to legal culture. From cultural character, Chinese culture belongs to the introverted culture, and Western culture belongs to extroverted culture. From the way of thinking, Chinese culture belongs to the holistic thinking culture, and Western culture belongs to individual thinking culture. From the perspective of cultural orientation, Chinese culture belongs to family oriented culture, and Western culture belongs to an individual oriented culture.

The natural rights. A person's status is based on "national". "People" is the purpose of the country, rather than "people" being for the sake of country. What the country has a duty to defend the rights of everyone is born with such as the right to life, the right to freedom from fear, reproductive rights, the right of knowledge, and the right to freedom from want, freedom of thought, freedom of expression, the freedom of the rally, this is the purpose of existence of a nation. Liberalists think that universal value is the real basis of a harmonious society, which perfectly interprets the other man, man and society, and a reasonable relationship with the country. Without universal values, social justice is a castle in the air. Nationalists deny universal values, they emphasize the value of individual existence only conform to the state's will to be meaningful. However, the country is made up of individuals. If it denies the value of the individuals, it is actually deny the value of the whole society.

The universal value set by Witesman (2016): (1) evaluating the contribution of government to society; (2) transforming general societal interests into government decisions; (3) arbitrating relationships between politicians and administration; (4) examining the relationship between government and the environment; (5) 
managing the internal function and organization of government; (6) describing the values of public employees themselves; and (7) describing the relationship between government and its citizen/users/customers. This universal value set is very helpful for further researches.

The unit of analysis is individual. The universal value research is a difference in the unit of analysis. Public value is observed primarily at the individual level. Most conceptions of public values are derived from psychological constructs, and research in this vein is centrally focused on the impact of various values and value sets on individual decision-making and individual action (Meynhardt, 2009, Schwartz, 1992).

The Buddhist equality implication. New Huayan Sutra (Vol. 53) gives 10 kinds of equality: the equality of all beings, equality of all laws, equality of all time, equality of all deep hearts, equality of all good, equality of all bodhisattvas, equality of all willing, equality of all jackfruit, equality of all behaviors, and equality of all Buddha. The universal values should be compared, create and recreate based on human beings heritage, including Buddhism.

\section{The Common Value}

\section{Human Common Value}

The common value for humanity is created by $\mathrm{Xi}$ Jinping, which is the part of public value. $\mathrm{Xi}$ Jinping proposed to construct the community of human fate at different occasions. He said, at the United Nations meeting in Geneva in 2017, pass on the torch of peace from generation to generation, sustain development and make civilization flourish. This is what people of all countries long for. It is also the responsibility that our generation ought to act on.

China's proposition of the community of human fate is the shared and win-win development. $\mathrm{Xi}$ Jinping (2015) said, "peace, development, equality, justice and freedom are the common values of humankind". He outlined an action plan, including: (1) to stay committed to build a world of lasting peace through dialogue and consultation; (2) to establish a world of common security for all through joint effort; (3) to create a world of common prosperity through win-win cooperation; and (4) to develop an open and inclusive world through exchanges and mutual learning. With the dramatic development and restructuring of the world, Xi put forward the ideas that concern the destiny of humanity, including the call for building a community with a shared future for Asia and humanity, which offers Chinese wisdom and Chinese approaches to the peace and development of the world, and the prosperity and progress of Asia.

The community with human fate is a concept for benefitting world peace and development. $\mathrm{Xi}$ Jinping stressed that realizing the full enjoyment of human rights by people is the common goal of human society at the Beijing Forum on Human Rights in 2015. In modern times, the Chinese people have experienced much hardship and are fully aware of the significance of human values, basic human rights and human dignity to social development and progress. China will unswervingly advance the cause of human rights both in China and in the world.

China has gradually absorbed the common civilized achievements and common values. These values include peace, development, equity, justice, democracy, freedom, equality, rule of law, human rights, science, efficiency, and global governance. The harmonious world view consists of five dimensions: political multi-polar, economic equilibrium, and diversified security, mutual trust, and environmental protection. It is certain that the common achievements of civilization and the common values of mankind are the basic value resources of the socialist core values. 


\section{Singapore's Common Value}

With the approval of the National Assembly, the Singaporean government published the White Paper on Common Values, formally proposing Singapore's common values in January 1991.

The country is the first, and society is the first. It is emphasized that when dealing with national, social, and individual interests, the local interests of each community and associations must be subject to the overall interests of the country, and individual interests must be subject to social interests and national interests.

The family is the root and the society is the base. It highlights the importance of the family as the basic rock of society and the cornerstone of the country's stability.

Care and support, respect for the individual. It emphasizes the inviolability of citizens' rights, respects and protects the individual's rights to the survival and development, gives sympathy and assistance to vulnerable groups in society, establishes a complete social security mechanism, and provides equal opportunities for competition.

Seek common ground while reducing differences and reach consensus through consultation. When problems and contradictions are encountered, there should be a spirit of forbearance and seeking common ground while reserving differences. The differences and contradictions should be resolved through consultation, dialogues and authoritative coordination.

The racial harmony and religious tolerance. Promote mutual respect and tolerance among people of all races and religions. It is not only based on Confucianism, emphasizing the priority of the state, society, and the family to individuals, but also reflects the value orientation of Western society in advocating individual freedom and independence and respecting individual rights. It is also compatible with the new needs of different groups in the transformation of modern society, emphasizing the spirit of consultation, consensus, stability, and tolerance.

\section{Hong Kong's Common Values}

Hong Kong's common values include: pluralism and inclusiveness, democracy and freedom, rule of law and integrity, professionalism and efficiency, and equality and integrity (Chen, Zheng, \& Liang, 2013). They are different from traditional Chinese ethic values.

\section{Japanese Common Values Discussion}

Japanese common values include group structure, group consciousness, competitive style, and enterprising spirit. These national spirits dominate the evolution and inheritance of Japanese culture. In Japanese value system, loyalty awareness and group awareness are at the core. Loyalty is the highest ethical morality and the core of the value of Japanese spirit. The group consciousness is formed in Japanese mutual cooperation. It is the core of Japan's modern spirit, and it is also the embodiment of loyalty consciousness in individual and collective relations. Underlying this sense of group is the deep-rooted interdependence of Japanese. The individual is dependent on the collective, and in coordination with others. The individual feels safe, if he finds his place of residence and realizes his own worth in it.

Performance and role of Japanese core value system. The common value system with loyalty and group consciousness is closely linked and exists at three levels: individual, social, and national. At the individual level, although Japanese are also influenced by Confucian culture, after combining with the social and political structure of Japan, loyalty, courage and faith are vital. 
Loyalty is the first important. Loyalty is embodied in the unconditional obedience of the lower person to the superior at the individual level, while the superior does not have to be kindhearted to the lower individual. The sense of loyalty is nurtured the selfless dedication, strong sense of mission, love and dedication of Japanese people, and creates the unique national spirit and temperament.

At the social level, the sense of loyalty turns into a sense of group, based on a strong sense of belonging. Individuals are loyal to their group and devote themselves selflessly to the group and maintain their actions as members of the group and others.

At the national level, a sense of loyalty and a sense of group are very strong. Japanese national identity and national consciousness are extremely strong and have strong national self-esteem due to the unity of Japanese in culture and language, and race, with the unique geographical environment of the nation's own survival.

\section{Comments: The Main Difference Between Chinese Common Value and Western Common Value}

Collectivism and individualism. The Chinese people's value of "unity of nature and man" will inevitably lead to collectivism orientation and other people's interests-orientation. People prefer to sacrifice their personal interests. They also need to worry about the society and the world.

The traditional Chinese philosophy is "unity of heaven and man", which refers to the obedience and worship of nature and the harmony and unity with nature. In ancient times, China had been "unity of nature and human beings".

The basic structures of traditional Chinese society: highly centralized bureaucracy, absolute monarchy, and patriarchal system. In essence, it is incompatible with individualism and forms group-based collectivism. The Chinese people advocate that everything should be based on the interests of the family, society, and nation. They advocate individual obedience to the collective and "great selflessness (da gong wu si)". In dealing with individual and collective relationships, people are required to be self-disciplined and consistent with the collective or leaders. In the relationship between the individual and the family, it is emphasized that the individual lives for the family. Individualism becomes a derogatory term relative to collectivism, and individualism is considered to be egoist.

The Western values have tended to conflicts between people and nature. They are the separation of heaven and man, emphasizing the power of human beings to fight against nature. The Western world emphasizes individualism, personality development, and self-expression. They think if a person cannot achieve his own purpose, he is lazy and lacks the aggressive spirit rather than his destiny.

Western culture is characterized by the emphasis on individual values, e.g., advocating individual independence, emphasizing individual initiative, enterprising, and cherishing individual rights. Individualism is the core of the Western culture. However, individualism owns multiple and complex nature. They believe that they can save themselves, seek self-expression, emphasize personal dignity, and pay attention to personal privacy and the impartible right of the individual. In the Western society, people generally regard individual freedom and individual rights as positive expressions of self-worth, and individual spirit. Each person tries to embody a personalized self, such as individual self-confidence, self-affirmation, free expression of inner feelings, free from external constraints, and public expression of different opinions.

The United States is a self-centered, highly individual freedom and the interests of the individualism. Americans believe that protecting individual rights and personal freedom is extremely vital. Individualism takes 
the family, the collective, groups and organizational members the second important. They put themselves in the position of higher than others.

The rights gap. The rights gap is the situation of inequality between people. It is a phenomenon that is prevalent in various socio-cultural groups. Different cultures also have different ways of dealing with the inequality of rights. Chinese culture belongs to the social structure of the order, and the Western culture belongs to the parallel social structure. The basic structure of Chinese society has always been the family with blood as the bond, and it is ethics that serves the patriarchal system. Power plays an important role in China. The Chinese hierarchy is rigid, and everyone has a fixed identity, status, rights and obligations in society.

The Western culture, especially the social structure of the United States, is basically parallel. The Westerners advocate freedom, equality and personal liberation. The Declaration of Independence of the United States stated that human beings are born equal, and the creator has given them their inherent rights, namely the right to live, freedom, and the pursuit of happiness. Freedom and equality are the ultimate survival goals of people.

Authority and equality. China advocates the authority. It is an expression of obedience to authority at the lower levels. The fact that subordinates must act according to the direction or intention of the leadership, respect the elders, and educate the children to obey. The priority of authority is directly related to Chinese culture and Confucianism. The traditional culture is based on the family and is maintained by blood. Under the influence of Confucianism, the formed interpersonal relationships are hierarchical, and the value orientation of interpersonal relations is emphasized. The essence of Confucianism is "benevolence" and "ritual", that is, people must stand on their own feet and on the other hand, they must help people. "Ritual" is the social behavior standard of people and advocates inner restraint so as to achieve benevolence, and society can achieve harmony. Confucius' ritual is ethics and emphasizes the difference in seniority. The principles of interpersonal relations advocated by benevolence including: Father and son have relatives, monarchs have righteousness, couples are different, children are orderly, and friends have faith. This is often referred to as the "Five Ethic Orders" idea. Confucius proposed that self-denial and etiquette refer to the communication criteria, such as "not to speak, not to look at, not to listen to", that is, to do things in accordance with their own identity. One of the outstanding features of the Chinese people is humility. The Chinese people are loyal, tolerant, righteous, trustworthy, courteous, and respectful of their teachers to have a harmonious and orderly society. However, Chinese people also inhibit personal desires. Traditional Chinese ethics limits human development, conservative thinking, pioneering, and enterprising spirit.

The idea of equality is deeply rooted in the United States. American families advocate equality rather than hierarchy. They treat children as adults and respect their personality. Children usually have their own views and ideas. Children can make their own choices. Americans also treat others equally, both in school and in their daily lives. They also want to be treated equally. People value their family background less, but pay more attention to their own abilities in their lives.

The values of equality are based on contractual relations and formed under the influence of ancient Western philosophy and religion. When people engage in business activities, the actors conduct transactions according to their own wishes. The relationship between them is equal, and only on the basis of equality can the transaction be concluded before the contract is finally concluded. Christianity advocates the equality of all people and even loves their enemies. The European Renaissance movement emphasizes the liberation of personality and freedom of personality, which lays the foundation for equality among all people. 
The main differences in interpersonal relations between China and the West. The interpersonal relationships in Chinese society tend to be emotional. The basic structure of Chinese society is hierarchy. The corresponding social relations and interpersonal relationships are "father and son have relatives, monarchs have justice, husband and wife are different, brothers treat orderly, and friends are trustworthy". The "Five Ethic Orders" not only constitute the moral standards that people generally abide by, but also become the basic norms of interpersonal relations. This relationship, developed on the basis of relationships between family members, friends and relatives, enables people to be interdependent and meet each other's needs, including emotions.

In the public service, public and private, personal emotional relationship, and public relation confusion are a typical emotional interpersonal model. The Western social relations tend to be instrumental. Everyone is equal, and parents and children are equal, and they can compete with each other.

The Western people's principles of interaction. The principles are self-interest, confrontation, competition, equality, independence, seeking differences, seeking new things, freedom, self-help, directness, attention to privacy, etc. This relationship is often based on the principle of fairness. People act according to the law, e.g., friends and relatives, people and things are clear, and public and private are distinct. They are not as sentimental as the Chinese who often use human feelings (face, mian zi) as a means of trading. In the Western culture, this form of rational and logical interpersonal communication that exceeds emotion is a typical interpersonal relationship model.

In short, Chinese values pay more attention to group consciousness and pursue the spirit of altruism, while the Westerners pay more attention to individual consciousness and prefer the idea of self-interest.

Monolithic and Pluralist value orientations. Chinese people are deeply rooted in the influence of Confucianism. They believe that the value of life is in the present world. The more a person has done in society, the more meaningful his life will be. In an autocratic society, power is everything. The greatest human being is to realize the ambition of politics. The big ideal of ruling the country is under the rule of royal family. Influenced by this unidimensional life value, most people do not want to pay attention to the natural sciences. Chinese mainstream cultural values are harmony and spirit. The Chinese nation has paid much attention to harmony since ancient times. In the relationship between man and nature, it advocates the unity of heaven and man, and the harmony between man and nature. In the relationship between people, it emphasizes on the value of peace, and be kind to others. The Chinese nation is a peaceful and friendly nation.

The mainstream of Western cultural values is the spirit of striving for self-satisfaction. Western culture promotes individuality, emphasizes the protection of personal interests, pays much attention to the independent development of personal potentials, and strengthens personal rights consciousness. Individualism is the rule of all behaviors, and self-realization is the highest demand and purpose of life. Independence is the most effective means to realize self. Human rights are inviolable and self-guarantee.

Interaction approach. The reasonable egoism, utilitarianism, pragmatism, existentialism, and private ownership economy have led people to form the concept of self-centered and personal supremacy in communication. The Westerners are extroverted, seeking independence, seeking utility, and advocating that human beings transform nature. The formation of these ideas and concepts has a direct relationship with their natural and social environment. People want to recognize nature, transform nature, conquer nature, and seek the most valuables in the outside world for their utilities.

Chinese ethical concept of maintaining hierarchical identity and the purpose of socialism. Serving the people requires individuals to integrate into the group, and the interests of the state, the collective and others, which is higher than individual interests. It is decided that the Chinese are introverted, implicit, modest, do not 
seek their utilities, the public is not private. The concept of the unity of nature and man also believes that people and nature should develop harmoniously instead of people and nature's fight. Interpersonal relationships are bound by intangible conventions and social norms, values, and etiquette. At the beginning of human beings, human nature is good, advocating that people return to nature and maintain their nature. Everything remains the same, kindhearted thoughts, the middle way, quiet and self-respecting, smooth living and working, incremental thinking, obedient to nature, self-satisfaction and happy. The Chinese people seek development while maintaining stability, seek stability rather than change, and pay attention to tradition and the past.

In the collective Chinese society, people are self-suppressed, euphemistic, and implicit in their communication, use their words carefully, pay attention to the observation of words, and have a high sensitivity and acceptability to the environment. Confucius's attitude towards language is cautious. He has always advocated that a gentleman wants to slow down and speak, but is sensitive to doing.

In an individually-oriented Western society, people are willing to express in their inner world, even if the trivial things. People are good at expressing themselves.

Family values. The Chinese take family as the priority. "Self-cultivation", "big family", "ruling the country", and "the world" are the outlines of a growing family value. Home is the universe of life in the eyes of the Chinese people and has supreme cohesion. In the family, there are relations between parents and children, and the relationship between husband and wife should be divided, and each of them should perform their duties. Mencius believes that the saint is "the people of humanity", and the core of ethic is "absolute obedience". The young serves chief, and the wife serves the husband. One of the reasons why the family has become so important is "filial piety" and "good filial piety is the first". Good filial piety is the national origin and quintessence of China.

Western culture highlights self, highlights individuals, and pursues independence. American family values run through the three main concepts of independence, rights and equality. The idea of American family happiness is based on the concepts of individual equality, independent development, and awareness of rights. The most prominent of these is the concept of independence and equality among family members.

Cultural values. Although values are acquired and everyone has a unique set of values, in every culture, there is always a universal value that is embedded in the culture. This value is called cultural value. Family values are the core of the study of cultural values, because the family is the initial environment in which cultural values are formed. The behavior and ideas of family members are bound to be influenced by the family. The family is the most basic unit of social form, so the formation of cultural values in the society is directly influenced by family values.

As a combination of cultures, these two different cultural entities necessarily embody different core cultural values. Chinese cultural values emphasize collectivism as the core, and individual interests should be subordinated to collective interests. In contrast, American cultural values emphasize individualism as the core with personal interests above all else.

The cultural values of the United States centered on individualism and the economic basis of individual business activities. It always regards profit as a healthy value pursuit. It encourages people to actively pursue real interests and compete on the basis of equality. Strive for personal best interests and happiness. In the United States, the sense of competition permeates the entire society and every family. In the American family values, the sense of competition is also a very important. They believe that competition can only make progress, and only in competition can they fully demonstrate their true ability. 
China is traditionally a community of values. Liu Jintian (2017) thought that Chinese civilization is universalism and humanism rather than nationalism and specialism. China is not a specific nation, ether. Chinese civilization takes the universal care of whole human beings as the starting point, and measures itself with human value.

The core of Western civilization confirms that the significance and rationality of individual self-interests. The core of Western civilization confirms that the significance and values of the public, which focuses on the whole world as one community. This is equality spirit, thus achieved true harmony.

The value system of Chinese and American cultures puts people at the center, but the understanding of people is very different. American culture emphasizes the status of human beings as independent individuals with reason, dignity, and free will. They require people to be responsible for their own destinies and rely on themselves. Therefore, in dealing with family issues, they must also reflect the concept of individualism at the center.

The main characteristics of traditional Chinese cultural values. They are the economic value of agriculture and trade, the political value of worshipping imperial power and pursuing power, and the moral value of honesty and shame.

Humanism. The basic meaning is to focus on human fate and to emphasize human interests above all else, calling for human peace, realizing the unity of human as the same. Think only from human interests and bring people a fair to guarantee the sustainable development of human beings.

Human social basic system. It is characterized by political democracy, economic democracy and education democracy, established a whole free citizen education system and perfect social security system, improve the social order, as well as the all-round development of more efficient mode. Political democracy demands for separation of powers, the realization of power from the people, and accepts the effective supervision of public opinion.

Economic democracy. It is to further eliminate traditional private property rights and leads to human interests be overdraft plunder and for private pleasure brought by the crisis of human beings. It is equal to establish a market by the whole economic system and enterprise management as well as government officials. It is effective supervision and restriction by shareholders.

Political system. Humanism as the instruction, everyone has equal legal rights, political democracy, justice, freedom, against the political, economic, the hereditary and monopoly of power, and objects to the oppression of political corruption and abuse of power and force. A fair election political regime is needed to ensure that every citizen reasonable expression of the will and implementation, and respect for the dignity of each person. This way can ensure the realization of the value, and maintain political stability and global human solidarity.

\section{Public Value and Comments}

Moore (1995) did not make a detailed and exact definition of public value. Public value is a category of individual/private values. It means the utility and significance of the same object that can meet the needs of different subjects and the public.

\section{Designed Value, Developed Value, Manufactured Value, Organized Value, Managed Value, Provided Value and Distributed Value}

Public value exists in the co-production and public life. Public value provides a useful way of thinking about the goals and performance. 
Public value can be specified to operational values, such as the designed value, the developed value, the manufactured value, the organized value, the managed value, the provided value, distributed value, etc. for performance evaluation. These values are mainly efficient values and equality values, and participants can play active roles.

\section{The Dimensions of Public Value: Services, Outcomes, and Trust/Legitimacy}

It covers outcomes, the means used to deliver them as well as trust and legitimacy. It addresses issues, such as equity, ethos, and accountability and it outlines three dimensions of public value: services, outcomes, and trust/legitimacy.

"Services" imply "what are public services" in the eyes of different social groups. "Outcomes" imply whether/why the services are good in the eyes of different social groups. "Trust and legitimacy" imply how the services are achieved through a variety of political, economic, social, and cultural institution.

\section{Characteristics of Public Value}

Public and civil. It is shared and non-exclusive, and is shared objects.

It is shared, but it is not necessary of "non-exclusive" services in China. Non-exclusive services are pure public services. However, there are other categories of public goods, such as common goods, collective goods, the club goods, etc. Public goods are distributed very differently at five administrative levels, and are distributed differently in different cities at the same level.

Social aspects. The standards, requirements, and services of public values vary somewhat between urban and rural areas, between affluence and poverty, and between people of different ages, but the overall values are consistent.

Values are related to norms, beliefs, virtues, ethics, behaviors, standards, requirements, and services, which is cultural oriented. The overall value can refer to common values, social values, dominant ethic values, even the socialist core values or universal values as well. Value diversity or value consistency will be highly argued, similar to localization or globalization argument.

Operability and enforceability. The public value system of the society can be established with the civil participation, which meets both the needs of social development and the needs of the public.

Values can be classified into ultimate values and instrumental values/operational values. Questions are: Are public values should be operational and enforceable? Are the ultimate values public values? Are the ultimate values related to religions, beliefs, politics, ideologies, and dominant core values? In Chinese context, "public" means mainly the ultimate values, such as "The World Is Public (tian xia wei gong)" and "The Big Public Without Selflessness (da gong wu si)". In Western countries, the ultimate values are from religions, while the ultimate values in China are from the dominant Party, such as the socialist core values.

Public participation and governance. Governance and management of public values is not monopolistic, but pluralistic, multi-modal and multidimensional, and thus is also a democratic, public governance and management model.

In China, democracy and participation are more difficult due to the centralized political system, governmental hierarchy, dominant Confucian ethics culture, and the underdevelopment of social associations. It is not easy to change the way of thinking, norms, virtues, ethics, beliefs, behaviors in current China though it is integrated with and the globalization. 


\section{The Review of Mark Moore's Public Value Management Model}

The theory of public value management. Multidimensional concepts and elements. The concept of public value was first proposed by Mark Moore (1995). In constructing the theoretical model of the Strategic Triangle in public sector, he pointed out that the entire mission and goal of the organization must be determined by the important public value of the organization.

In China, all public organizations are the units of the national hierarchy with five to six levels. The dominant public value is the socialist cores value in whole public sector.

In Moore's view, it is impossible to have a clear definition of public value, because public value itself is not an absolute standard concept. It needs to be specifically analyzed in specific issues in a specific policy environment.

In China, the national public value as unification is designed by central government. Chinese way of thinking is holistic and top-down approach that is different from the Western world.

Although Moore's research on public value did not form an exact conceptual system, it has attracted many scholars to discuss the public values and form a multi-dimensional interpretation.

The key words of "public" and "value" are very broad and complex for interpreting and explanation in both China and the other world. "Public" and "value" concern about multiple disciplines of philosophy, ethics, politics, culture, economics, sociology, history, public policy, psychology, governance, etc. rather than public policy and management. They needs to be sought for, compared, analyzed systematically with both the contexts, a variety of ethical frameworks, related individual/group interests, and even politics.

Kelly, Mulgan, and Muers (2002) believed that in a democratic system, public value is considered to be defined by the public itself, determined by public preference, expressed through a series of means, and finally reflected by the decision of the elected official.

In China, the political system is a top-bottom design, and the hierarchical administrative government is implemented from top to bottom. The definitions, preferences, expressions, and decisions of public values are dominated in the hands of government. It is required of "the unity of thinking/ideology" and "the consistency of politics, organization and action". The political cultures are so different in the world. This is also the generally accepted definition of public value so far. Public value is mainly determined by public preference, which is the core of public value.

In China, public preference takes place in a relatively closed social system, in seeking common thinking, official value indoctrination, and marginalization of non-traditional values. The result is a convergence of public preferences due to the high context and social cohesion of collectivism.

Some scholars point out from the perspective of public service output that the concept of public value should be distinguished from public goods and public interests. Alford and O'flynn (2012) believed that public value includes public goods, but the former has a broader connotation.

Moore (2013) thought that public value is services (the questions are: What is public service and how to redefine public service?), outcomes (the question is who evaluate output/outcomes/impact and the result make differences), and trust/legitimacy (the question is how the public trust or how legitimize public services politically, economically, socially, and culturally?). "Public" is not only the dichotomy of private and public (it is the strong society and the weak government structure in the Western world).

In traditional China, public is defined as: (1) individual public thinking (public heart/soul to serve people with whole hearts and souls, which is the mission of the Party); cultivate one's morality (xiu shen); a man of 
noble (jun zi); (2) Confucian ethical values, which dominate both all families and the whole society; and (3) national value, such as patriotic, to love the Party, to love motherland, and to love people. It is priority of national value with the value ranking from national value, to social value, to individual value. If the three values are conflicted, individual value is subject to social value, and social value is subject to national value. This is cultural value make a judge rather than law orientation in the everyday life.

Two different criteria are significant for both China and the Western countries: (1) Rule of law (fa zhi) versus rule of ethics (de zhi) that is easy to rule of man (ren zhi). Generally, traditional China is ruled of ethics rather than ruled of law; and (2) individualism versus collectivism, which concerns about "the same social structure of "family/clan and kingdom/nation", and the impact is the strong family organizations and the strong kingdom/nation organizations, which are ruled of (group/public) ethics, while the social associations and social organizations are absorbed in families/clans and the kingdom/nation. In the transitional China, these two issues are not solved yet.

Stoker (2006) saw public value as an independent paradigm and as the latest method to balance efficiency and democracy.

It is hard to separate public values from efficiency (especially in term of public management, public policy, and outcome). It is hard to separate from public value from democracy since civil participation, and trust and legitimacy are basically consisted of democracy.

Christensen \& Laegeid (2007) believed that the public value paradigm can be seen as the "post-public management" thinking.

This idea is significant for the future world. Traditional public management thinking is to choose one perspective from an authority value or a scholar's value as management value, as goals, criteria, approaches, methods, and evaluation. Now public value thinks that all these can be completed democratically, humanly, and collaboratively. But how the post public management is operated and to be explored?

In Smith's (2004) view, public value in public administration can satisfy the need for a "new story". This outline can promote the assessment. If analyzed from the perspective of policy evaluation, public value can even be regarded as a "performance measurement framework".

If we take the public value theory as an open system perspective, it is not only policy evaluation, public policy and public management traditionally. It is a new paradigm that focuses on participation, democracy and governance, especially virtues/ethics. For Chinese traditional heritage, the most important factor is people with diversity of contexts. Therefore, virtues, ethics, values, leadership, culture, and tradition are more important than other fixed design.

Public value consists of three main aspects: service, result, and trust or legitimacy. First, the value from public service mainly refers to the value set of customer satisfaction, organizational culture, and its fair elements. Second, the value from results is broader than that from public services and exists as an organization's long-term strategic goal. It is an important indicator of the organization's authorization and legitimacy. Finally, the value of trust is closely related to legitimacy, including the level of social trust and the tendency to trust in the system.

In China, it is not usual to have the organizational culture and fair system evaluation. It is true that Chinese government make a long term strategy that is Chinese cultural characteristic. As far as legitimacy, the trust in government, especially the higher level of government, is the priority for Chinese culture. The level of social trust is a big problem due to the big change of society including urbanization. The trust is a big problem 
between persons and between groups. However, the trust in government and nation is very high that highly depends on ethical values/culture.

Definition of public value through political consultative networks. In Moore's view, there is a strong link between individual voluntary choice and the provision of quality public services. Good public services and policy outcomes cannot be achieved without the voluntary choice of individual citizens. Therefore, voluntary selection is seen as an important prerequisite for the creation of public utilities and the improvement of resource utilization.

In China, it is unclear between individual choice and the provision of quality public services, between individual voluntary choice and the provision of quality public services. It is also unclear that the voluntary selection as an important prerequisite for the creation of public utilities. China is a very different nation in which individualism, volunteering, and non-profit organizations (NPOs) are quite weak traditionally.

The collection of individual expectations of citizens constitutes the public values. It can be seen that the process of defining public value is the process of exploring public preference. Only public preferences being defined can public value be defined, but the former is a dynamic and political process.

It is so unclear that how individual norms, individual preference, group preference, group values, and public value are constructed. However, it is clear that the realization of the process is cultural oriented and democratic process in the public domain/space.

\section{Define the Importance of Public Value}

In Moore's (1995) view, around public values, managers can constantly review and evaluate their authoritative environment based on potential environmental changes, and have to consider the feelings of the public, client groups, beneficiaries, and other stakeholders. Governments have to think about whether the decision itself reflects the real wishes and needs of the citizens.

It is the reasonable to China's situation. The Chinese tradition and administrations always focus on environmental change and adopt a strategic/long-term goal. The objectives are depended on local situation as well as sub-goals of the national strategy. The problem is that public value is systematically defined from central or upper level, rather than social stakeholders and real wishes/needs. It is a centralized or decentralized, democratic or undemocratic problem.

Rhodes (2000) pointed out that cooperative governance requires that the government's response to the public needs to be based on openness, competition, and order. The most critical thing for government action is to have an adaptive and flexible response mechanism. In Jessop (1999) view, careful thinking about how to establish a flexible response mechanism is related to the realization of the expected results.

China is always emphasizes on social order/stability (wei wen), and increasing competition, but not good at openness. In reality, openness, such as public hearing, public debate, direct election, transparency, and participation in decision-making is not traditional Chinese culture, which is different from Western countries.

Aldridge and Stoker (2002) argued that cooperative governance with public values at its core must reflect the spirit of public service, that is, open and flexible public service delivery: A culture of performance, the ability to take responsibility, support wider access, be responsible for employers, and be committed to community welfare.

The spirit of public service is operational, which is different from public service spirit in China, which is instilled by both national value and traditional values. It is unusual of supporting wider access and being committed to community welfare in China. 


\section{Achieving Public Value Through Effective Accountability and Evaluation Systems}

Public value management believes that the liability mechanism must operate around the realization of public value, that is, responsibility should be determined by the negotiated and communicable goal and its supervision. Since the realization of efficiency is that the governing body continuously ensures that its behavior is in line with the goal of creating public value, responsibility must be the evaluation of the continuity of action by the manager to ensure the realization of public value.

The operational is uniqueness of achieving public value in Western management, especially in strategic management. However, for most Chinese public organizations, the annual performance evaluation focuses on personal evaluation rather than organizational one. Personal evaluation list is composed of five items, such as virtues (de), competency (neng), diligence (qin), performance (ji), and incorruption (lian) all over of China every year. Most of the list belongs to ethical values.

For Chinese organizational evaluation is very flexible and benefits individuals. The liability mechanism of individuals is stricter under the peer's mutual supervision. The liability mechanism of organizational public value is quite different. In China, it is centralized government in the perspective of resource dependent theory. If public value of an organizational evaluation is low, the leaders, units, and employees are much affected, such as the government budget, their jobs, position promotion, and salaries, bonus, etc. Therefore, it is impossible to have an effective accountability and real evaluation systems because politics and organizational interests are the key rather than "public value".

Public values need to be realized in the form of cooperation and dialogue between different governance subjects in the network. Therefore, responsibility not only requires managers to comply with laws, social values, political norms, and professional standards, but also needs to continuously respond to citizens' expectations.

All public managers are under the government. Their autonomy is very limited under the laws, social values, political norms, and professional standards and citizens' expectations. In terms of outlook on life and values, Chinese emphasize that cultivation is the basis and put "virtues" at the top of values; Western thinkers emphasized the importance of "true".

Public values are those providing normative consensus about: (1) the rights, benefits, and prerogatives to which citizens should/should not be entitled; (2) the obligations of citizens to society, the state and one another; and (3) the principles on which governments and policies should be based (Bozeman, 2007).

This is rule of law with clear rights and obligations of citizens, and the principles of rule. However, what the written laws is one thing, what public values operation is another. The biggest difference in China from Western countries is the role of the Party system and related socialist core values. The big difference of Chinese political culture is the unclear rights and obligations of citizens. Many policy concepts are not defined with a variety of meanings and preferences whatever they could recreate. The implementation is integrated with the specific practices as a national characteristic.

Value for the public is a result of evaluations about how basic needs of individuals, groups, and the society as a whole are influenced in relationships involving the public. Public value creation is situated in relationships between the individual and society, founded in individuals, constituted by subjective evaluations against basic needs, activated by and realized in emotional-motivational states, and produced and reproduced in experience-intense practices (Meynhardt, 2009). 
The basic needs evaluation of individuals, groups, and the society is a good point. In China, the priority is national value or central government value. However, the pubic value is boarder than basic needs evaluation. It is instilled national value and more spiritual.

Witesman's (2016) framework provides a valuable structure: (1) How individual public values are identified; (2) How these values are selected and organized to produce individual preferences that are synthesized from multiple public values within or across varying contexts; (3) How aggregation mechanisms and institutional decision rules are used to express and aggregate individual values and preferences to create group values and preferences; (4) How such institutions result in specific decisions or actions that represent the collective interest that must be implemented to produce ends/results/outputs that are perceived and valued in sum according to whether or not they produce public value.

It is a useful performance evaluation model of public value. This is one of the most detailed and operational public value construct. It is better to have some case studies in China and other countries to verify this model. In China, the differences are: (1) collective/group public value rather than individual public value; (2) political preferences rather than individual preferences; (3) instill collective/group public value rather than aggregate individual values and preferences; and (4) the public value as socialist core value in China.

\section{The General Remark}

Public value is very useful and easy to be accepted for Chinese people due to the recognition of "public" (gong) and "value" as tradition common ethics. There are some uniqueness in Chinese tradition: (1) collectivism rather than individualism; (2) rule of virtual/ethics rather than rule of law; (3) the traditional China adopted "public value" as governing approach for more than 2,500 years since the creation of Confucian value. All kingdoms in China instill "public value" to individuals, groups, the whole nation; (4) the hierarchy of government rather than decentralized government; (5) the Party system as a major difference; (6) public value is from the top and less civil participation; (7) the purpose of public is to provide public services/public goods, that is not the whole image in China. "Public" is the ultimate value, such as good virtues, the perfect character (jun zi), ultimate ideal (the world being public, tian xia wei gong); (8) in traditional China, the private cannot put on the table. The private rights preferences are as shame from traditional ethics. Public as a personal goal and ultimate value, and the king's highest value is "justice (zheng), the biggest (da), sunshine (guang), and brightness (ming)" to govern the nation; and (9) public approaches include fairness (gong ping), justice (gong zheng), and openness (gong kai).

Mark Moore's public value is created within performance evaluation, public policy and strategic management. It is significant of the public value paradigm which directs to what is ultimate value and public value chain management for integrating different actors, processes, outcomes, frameworks, contexts/environment, and institution for public services. But in China, "public" is as the ultimate goal, the ideal, the good virtues, the good theory (gong dao), good approach, good governance, good world and public nature of administration. If everyone is public (tian xia wei gong), the world is the same (da tong shi jie). This is the ultimate value of persons, groups, nations, and the world.

For the frontier public administration theory of public value, it is important to describe at the beginning what is public value in different nations, contexts, ethics, and cultures. Then compare, select, verify different public values. Why Confucius advocates the dominant ethic values? It is intense conflicts and fierce fighting at personal level, social level, and national level in the world, incompatible values resulting in conflicts. The 
dilemma are how to balance individual rights and responsibilities, how to balance nation and society, how to balance efficiency and equality, how to balance rule of law and rule of ethics, how to balance culture and modernity, how to balance modernity and post modernity, and how to balance different conflicting civilizations. People get together because we are "public", and people are different because we have different values". Public values make public administration diverse, both pros and cons but it is key in future, which depends on what public value is, to be sought for, to be created and recreated with the raging times tide.

\section{References}

Abernach, J. D. (1990). Keeping a watchful eye: The politics of congressional oversight. Washington, D.C: Brooking Institution.

Aldridge, R., \& Stoker, G. (2002). Advancing a new public service ethos. New Local Government Network. Retrieved from https://www.waterstones.com/book/advancing-a-new-public-service-ethos/rod-aldridge/gerry-stoker/9781903447215

Alford, J., \& O'Fiynn, J. (2012). Public value: A stocktake of concept. Presented at the Twelfth Annual Conference of the International Research Society for Public Management (IRSPM XII), 26th to 28th March, Brisbane, Australia.

Benington, J. (2011). From private choice to public value. Retrieved from https://citeseerx.ist.psu.edu/viewdoc/download?doi=10.1.1.532.7958\&rep=rep1\&type=pdf

Bentham, J. (1789). An introduction to the principles of morals and legislation. Retrieved from https://www.econlib.org/library/Bentham/bnthPML.html

Bovaird, T. (2008). Basing strategy in the public sector on the concept of public value (Unpublished work in progress, University of Birmingham, 2008).

Bozeman, B. (2007). Public values and public interest: Counterbalancing economic individualism. Washington, D.C.: Georgetown University Press.

Bozeman, B., \& Straussman, J. D. (1990). Public management strategies. San Francisco: Jossey-Bass Publishers.

Chen, D. N., Zheng, T. X., \& Liang, Q. T. (2013). The exploration of core values in Hong Kong. Journal of Lingnan, (3), 18-23.

Christensen, T., \& Laegeid, P. (2007). Transcending new public management: The transformation of public sector reforms. Aldershot, UK: Ashgate.

Domberger, R. S., \& Fernandez, P. (1999). Public-private partnership for service delivery. Business Strategy Review, 10(4), 29-39.

Elinor, O., Schroeder, L., \& Wynne, S. (2000). Institutional incentives and sustainable development: Infrastructure policies in perspective. Bounder, San Francisco and Oxford: Westview Press.

Frissen, P. (1999). Politics, governance and technology: A postmodern narrative on the virtual state. Northampton, MA: Edward Elgar Publishing Limited.

Haidt, J, (2012). The righteous mind: Why good people are divided by politics and religion. New York: Vintage Books.

He, Y. L. (2018). Public value management: A new paradigm of public administration. Retrieved from http://govreform.cupl.edu.cn/info/1022/5073.htm

Hu, J. T. (2003). Democracy is the common pursuit of all mankind, Join hands to create a bright future for China Australia comprehensive cooperative relations. Retrieved from http://www.sina.com.cn

Jessop, B. (1999). The rise of governance and the risk of failure: The comments on the case of economic development. International Social Science, (1), 31-48.

Kelly, G., Mulgan, G., \& Muers, S. (2002). Creating public value: An analytical framework for public service reform. London: Cabinet Office.

Liu, J. T. (2017). Observation and ponderation, No. 11, 29.

Marangos, J. (2006). Contrasting primitive conceptions of on basic income guarantee. International Journal of Environment, Workplace and Employment, 2(1), 6-20.

Meynhardt, T. (2009). Public value inside: What is public value creation? International Journal of Public Administration, 32(3-4), 192-219.

Moore, M. H. (1995). Creating public value: Strategic management in government. Cambridge, MA: Harvard University Press.

Moore, M. H. (2013). Recognizing public value: Developing a public value account and a public value scorecard. Cambridge, MA: Harvard University Press.

Rhodes, R. (2000). Governance and public administration. In J. Pierre (Ed.), Debating governance. Oxford, UK: Oxford University Press. 
Rokeach, M. (1973). The nature of human values (Vol. 438). New York: Free Press.

Russell, B. (2000). The collected papers of Bertrand Russell, Volume 15-Uncertain paths to freedom: Russia and China 1919-1922 (1st ed., R. A. Rempel, B. Haslam, and K. Blackwell, Eds.). London: Routledge. Retrieved from https://philpapers.org/rec/HASTCP-2

Sartori, G. (1997). New ideas on democracy. (K. L. Feng and K. W. Yan, Trans.). Beijing: Oriental Press.

Schwartz, S. H. (1992). Universals in the content and structure of values: Theoretical advances and empirical tests in 20 countries. Advances in Experimental Social Psychology, 25, 1-65.

Schwartz, S. H. (1994). Are there universal aspects in the structure and contents of human values? Journal of Social Issues, 50(4), $19-45$.

Smith, R. (2004). Focusing on public value: Something new and something old. Australian Journal of Public Administration, 63(4), 68-79.

Stoker, G. (2006). Public value management: A new resolution of democracy and efficiency tradeoff. American Review of Public Administration, 36(1), 41-57.

Stoker, G. (2007). Public value management: A new resolution of democracy and efficiency tradeoff (Unpublished paper, Institute for Political and Economic Governance, University of Manchester, United Kingdom, 2007).

Stoker, G., Maloney, S. G., \& Young, S. W. (2004). Voluntary organizations and the generation of social capital. In M. Boddy and M. Parkinson (Eds.), City matters: Competitiveness, cohesion and urban governance. Bristol, UK: Policy Press.

Talbot, C. (2006). Paradoxes and prospects of "public value". Paper presented at 10th International Research Symposium on Public Management, 10th-12th April, Glasgow, Scotland.

Veenstra, A. F. V., \& Janssen, M. (2012). Investigating outcomes of t-government using a public value management approach. Retrieved

from https://www.semanticscholar.org/paper/Investigating-Outcomes-of-T-Government-Using-a-Veenstra-Janssen/8a9122c0531d 12236cb9805d1e4d601f504cc433

Wen, J. B. (2007). Wen Jiabao: Like any truth, democratic system should be tested by practice. Wen Jiabao's talk to correspondents on two sessions. Retrieved from www.Chinanews.com

Wen, J. B. (2012). Speech at Tsinghua University. Retrieved from www.Chinanews.com

Witesman, E. (2016). From public values to public value and back again. Retrieved from https://cord.asu.edu/sites/default/files/wp-content/uploads/2015/02/2015123001-Public-value-to-public-values-and-back-forPVC1.pdf

Xi, J. P. (2015). We will work together to build a new era of win-win cooperation and build a community of common destiny. Speech at the General debate of the seventieth session of the United Nations General Assembly, 28th September-3rd October, United Nations. 


\section{Appendix: Further Questions}

1. Moore's category of public and private value vs the integration of ethic values and practice in China.

However, at the Confucian's time, there is no private/privacy right. So, public is not usual.

2. Theories vs practices + virtues/ethics?

Virtues/ethics plays important role between them. This is Chinese characteristic.

3. Ultimate value and operational value vs integration of ultimate value and operational value?

4. Is public value instilled? What is the role of human nature? What is the role of power? What is the role of religions?

5. Is public value imported? Freedom (Translator Yan Fu imported freedom, etc. in the book On liberty by John Stuart Mill in 1903.It is only 115 years compared with thousands of ruling history that Chinese first know the word freedom. However, even Yan Fu, Sun Yat-sen, and Mao Zedong did not understand its meaning, not mentioning of ordinary people), human rights, liberty, democracy, individualism, rule of law, public virtues, and equality.

6. Public value is cultural oriented? How about cultural conflicting values?

7. Public value should be ideal/idealism vs pragmatic/materialism?

8. The ultimate goal of public value is public service vs "how to be a person"/humanity?

9. Public value is multiple disciplines rather than public policy/public management/strategic management?

10. What impact of public value to the academy, a nation, the world? How to create a harmonious society, a harmonious world without fighting? 